which market value would be assessed at the five-yearly reviews of the licence fee. The fact that, as a result of provisions in the Telecommunications Code (Schedule 2 to the Telecommunications Act 1984), the equipment might well remain in place beyond the 20-year term of the licence, possibly even without a further faculty, meant that in the future the licence fee payable might become very small in real terms. Accordingly, while the chancellor did envisage granting a faculty as sought, it would not be granted until he had received satisfactory answers to the concern he had raised. [Alexander McGregor]

\title{
Re St Thomas, Kilnhurst
}

Sheffield Consistory Court: McClean Ch, 11 July 2012 Gravestones - replacement - duties of incumbent

Fifty-five years after the deceased's death, the petitioner's aunt had replaced the gravestone over the deceased's grave with one that omitted reference to the deceased's wife and son. The deceased's son petitioned to remove the replacement and erect a replica of the original stone, which had unfortunately been destroyed. The incumbent at the time had made inadequate checks when granting the application for the second headstone and as such had not appreciated that it was a replacement stone. The chancellor noted that the owner of a headstone is the person who commissioned and paid for it and, upon their death, the heir-at-law of the person commemorated. Incumbents have a duty to make appropriate checks in relation to applications to erect a gravestone, to check that the applicant has standing to make the application. A faculty was issued to allow removal of the second headstone and its replacement with a replica of the original. [Catherine Shelley]

doi:10.1017/So956618X12001032

\author{
JGE v Portsmouth Roman Catholic Diocesan Trust \\ Court of Appeal: Ward, Tomlinson and Davis LJJ, 12 July 2012 \\ [2012] EWCA Civ 938 \\ Vicarious liability-diocese-priest
}

The Portsmouth Roman Catholic Diocesan Trust appealed against a decision of the High Court that it was vicariously liable for the torts allegedly committed by a parish priest in their diocese. In a majority judgment the court dismissed the 
appeal. Though it was common ground that a priest was not an employee, an examination of the recent cases on clergy employment indicated that whether or not there was a contract of service between a minister of religion and his Church depended on the facts of the case, that there was no general presumption of a lack of intent to create legal relations between a cleric and the Church and that it did not follow that an ecclesiastical office-holder could not be employed under a contract of service. The court held that Viasystems (Tyneside) $v$ Thermal Transfer (Northern) Ltd [2005] EWCA Civ 1151 had established that for the purposes of vicarious liability the tortfeasor did not have to be an old-fashioned employee. Davis LJ stated that the time had come to announce emphatically that the law of vicarious liability has moved beyond the confines of a contract of service. Leave to appeal was refused. [Frank Cranmer]

\author{
Khaira and others v Shergill and others \\ Court of Appeal: Mummery, Hooper and Pitchford, LJJ, 17 July 2012 \\ [2012] EWCA Civ 983 \\ Religious doctrine - non-justiciability
}

The claim concerned disputes about the trusteeship and governance of two gurdwaras used by members of the Sikh community. The dispute centred upon whether the ninth claimant was entitled to exercise a power to remove and appoint trustees as the 'successor' of the First Holy Saint. The defendants wanted the court to grant a permanent stay because the contested claim to be the successor turned on matters of religious faith, doctrine and practice, which would involve comparison of the doctrines of mainstream Sikhism and the Nimral Kuita institution. The Court of Appeal allowed the defendants' appeal, holding that the High Court had erred in treating the particular core issue as one that was properly justiciable by the English courts. Mummery LJ held that the question of succession is essentially a matter of professed subjective belief and faith, on which secular municipal courts cannot possibly reach a decision, either as a matter of law or fact. The principle of non-justiciability therefore applied. Although there was no general principle that religious bodies or groups enjoy a spiritual independence or freedom that places them above, or exempts them from, the law of the land, or that religion inhabits a 'civil rights-free zone', the principle of non-justiciability meant that the courts will abstain from adjudicating on the truth, merits or sincerity of differences in religious doctrine or belief and on the correctness or accuracy of religious 